http://dx.doi.org/10.18778/7969-145-6.12

KRZYSZTOF STEFAŃSKI

\title{
Realizacja prawa do wypoczynku w przepisach o czasie pracy
}

Papież Jan Paweł II w swym nauczaniu mówił o wypoczynku wielokrotnie w różnych kontekstach. Wypoczynek, który ukazywał Papież, stanowi potrzebę każdej jednostki, służącą odzyskaniu spokoju, kultywowaniu życia rodzinnego, rozrywce, a nade wszystko - kontemplacji i modlitwie ${ }^{1}$. Potrzeba korzystania z „odpowiednich okresów wypoczynku, pozwalających odzyskać siły i zarazem odnaleźć właściwą równowagę duchową” jest szczególnie doniosła „we współczesnym, pochłoniętym często przez gorączkową aktywność i bardzo konkurencyjnym, w którym dominuje logika produkcji i zysku, nierzadko ze szkodą dla człowieka"2. Ważne jest, jak podkreślał Ojciec Święty, zachowanie równowagi między pracą a odpoczynkiem oraz życiem osobistym i rodzinnym³ ${ }^{3}$. Jednocześnie Papież traktował prawo do wypoczynku jako jedno z podstawowych uprawnień pracowniczych, obok prawa do godziwego wynagrodzenia czy uprawnień socjalnych. W encyklice Laborem exercens Jan Paweł II określił minimalny zakres tego uprawnienia - jako prawo do regularnego wypoczynku tygodniowego, obejmującego przynajmniej niedzielę, oraz dłuższego wypoczynku (urlopu) raz do roku lub krótszego kilka razy w roku. Można zatem uznać, że prawo do wypoczynku powinno być realizowane poprzez udzielanie pracownikom czasu wolnego codziennie (czy też w każdym tygodniu) i corocznego urlopu wypoczynkowego.

" Dr KRzYsztof Stefański, Katedra Prawa Pracy, Wydział Prawa i Administracji, Uniwersytet Łódzki, 90-232 Łódź, ul. Kopcińskiego 8/12.

1 Jan PAWEk II, Odnaleźć równowage duchową, Rozważanie przed modlitwą „Anioł Pański” 23 VII 2000 r., http://www.opoka.org.pl/biblioteka/W/WP/jan_pawel_ii/modlitwy/ap_23072000.html [dostęp: 5.11.2013].

2 Ibidem.

3 Jan Pawet II, Kultura ludzi pracy musi pozostać kulturą solidarną, List Ojca Świętego do uczestników zgromadzenia generalnego Światowego Ruchu Chrześcijańskich Ludzi Pracy, 7 V 2000 r., http:// www.opoka.org.pl/biblioteka/W/WP/jan_pawel_ii/listy/praca_07052000.html [dostęp: 5.11.2013]. 


\section{Prawo do wypoczynku w regulacjach międzynarodowych i europejskich}

W prawie międzynarodowym zasada prawa do wypoczynku jest przyjmowana jako jedno z praw socjalnych przysługujących pracownikom. Można zauważyć, że realizacja tego prawa jest związana, podobnie jak to określił Jan Paweł II w encyklice Laborem exercens, z regulacją czasu pracy i urlopów wypoczynkowych. Wymienić tu należy Powszechną Deklarację Praw Człowieka, która w art. 24 do prawa do wypoczynku włącza „rozsądne ograniczenie godzin pracy i okresowe płatne urlopy". Regulację prawa do wypoczynku zawiera także Międzynarodowy Pakt Praw Gospodarczych, Społecznych i Kulturalnych wskazując, że stanowi ono część prawa do korzystania ze sprawiedliwych i korzystnych warunków pracy. Na prawo to, stosownie do art. 7 lit. D Paktu, składa się wypoczynek, czas wolny, rozsądne ograniczenie czasu pracy oraz okresowe płatne urlopy.

Prawo do wypoczynku stało się także przedmiotem działalności prawodawczej Międzynarodowej Organizacji Pracy (MOP), zwłaszcza w zakresie ograniczania czasu pracy ${ }^{4}$. Praktyka taka widoczna jest już w konwencji nr 1 z 1919 r. $^{5}$, która ograniczała czas pracy w zakładach przemysłowych do 8 godzin na dobę i 48 w tygodniu. Kolejne unormowania ograniczające czas pracy wprowadzała m.in. konwencja nr 30 z 1930 r. dotycząca uregulowania czasu pracy w handlu i w biurach ${ }^{6}$, nr 43 z 1934 r. dotycząca czasu pracy w zautomatyzowanych hutach szkła płaskiego ${ }^{7}$, nr 47 z 1935 r. dotycząca skrócenia czasu pracy do czterdziestu godzin tygodniowo. Drugim kierunkiem działań podejmowanych przez MOP było wprowadzenie minimalnych okresów odpoczynku. Stało się to motywem przewodnim w konwencji nr 14 z 1921 r. dotyczącej odpoczynku tygodniowego w zakładach przemysłowych ${ }^{8}$ a także w konwencji nr 106 z 1957 r. dotyczącej cotygodniowego odpoczynku w handlu i w biurach ${ }^{9}$. Innym, istotnym z punktu widzenia prawa do wypoczynku, kierunkiem działań prawodawczych MOP było ograniczenie pracy w porze nocnej dla kobiet i młodocianych. Wśród konwencji regulujących tę kwestię należy wymienić konwencje nr 4 i 6 z 1919 r. ${ }^{10}$, nr 41 z 1934 r. ${ }^{11}$, nr 79 z 1946 r. $^{12}$, nr 89 i 90 z 1948 r. ${ }^{13}$. Wspomnieć także trzeba,

${ }^{4}$ Z. GóRAL, O kodeksowym katalogu zasad indywidualnego prawa pracy, Warszawa 2011, s. 180 .

5 Konwencje i zalecenia Międzynarodowej Organizacji Pracy 1919-1994, t. 1: 1919-1967, Warszawa 1996, s. 1.

6 Ibidem, s. 123.

7 Ibidem, s. 174.

8 Ibidem, s. 44.

9 Ibidem, s. 523.

10 Ibidem, s. 10, 18.

11 Ibidem, s. 171.

12 Ibidem s. 333.

13 Ibidem, s. 366. 
że działania MOP, choć w znacznie skromniejszym zakresie, dotyczą uprawnień urlopowych pracowników.

Działania prawodawcze MOP z pewnością służą realizacji prawa do wypoczynku, choć wspomnieć trzeba, że nie był to najważniejszy cel ich podejmowania. Wskazywano, iż konieczność m.in. ograniczenia czasu pracy wynika z troski o ochronę zdrowia i bezpieczeństwa pracowników, a w niektórych przypadkach (np. konwencji nr 47) jest to walka z problemem bezrobocia ${ }^{14}$.

Prawo do wypoczynku stanowi także przedmiot regulacji prawa międzynarodowego o zasięgu europejskim. Europejska Karta Społeczna traktuje to prawo jako szczególny aspekt prawa do odpowiednich warunków pracy. Jak podkreślono w literaturze, odpowiednie warunki pracy polegają m.in. na zapewnieniu pracownikom rozsądnego dobowego i tygodniowego czasu pracy, który powinien ulegać stopniowemu skracaniu. Ponadto należy wprowadzić tygodniowe okresy odpoczynku, które w miarę możliwości powinny pokrywać się z uznanymi przez tradycję danego regionu czy kraju dniami wolnymi ${ }^{15}$.

Prawo pierwotne Unii Europejskiej nie reguluje prawa do wypoczynku. W prawie wtórnym zasada ta znalazła swój normatywny wyraz dość późno, dopiero bowiem w dyrektywie Rady Unii Europejskiej 93/104 z dnia 23 listopada 1993 r. w sprawie niektórych aspektów organizacji czasu pracy ${ }^{16}$. Akt ten został znowelizowany dyrektywą Parlamentu Europejskiego i Rady 2000/34/WE z dnia 22 czerwca 2000 r. ${ }^{17}$, a następnie zastąpiony obecnie obowiązującą dyrektywą Parlamentu Europejskiego i Rady 2003/88/WE z dnia 4 listopada 2003 r. w sprawie niektórych aspektów organizacji czasu pracy ${ }^{18}$. Dyrektywa zawiera szereg unormowań dotyczących ograniczania czasu pracy, wprowadzania obowiązkowych okresów odpoczynku pracowników oraz urlopów wypoczynkowych. W literaturze zwrócono uwagę, że istotne w kontekście prawa do wypoczynku są, zawarte w dyrektywie, pojęcia czasu pracy i okresu odpoczynku ${ }^{19}$. Stosownie do art. 2 pkt 1, czas pracy jest to każdy okres, w którym pracownik pracuje, jest do dyspozycji pracodawcy oraz wykonuje swoje działania lub spełnia obowiązki, zgodnie z przepisami krajowymi lub praktyką krajową. Natomiast zgodnie z art. 2 pkt 2, okresem odpoczynku jest każdy okres, który nie jest czasem pracy. Widać tu wyraźnie, że pojęcia te wykluczają się wzajemnie. Dyrektywa ogranicza przeciętny tygodniowy czas pracy pracowników do 48 godzin wraz z godzinami nadliczbowymi. Przewiduje także obowiązek wprowadzenia dwóch okresów odpoczynku

14 Por. A. SoвczYk, Zasady prawnej regulacji czasu pracy, Warszawa 2005, s. 50.

15 Z. Góral, op. cit., s. 181.

16 Dz. U. UE L, nr 307, poz. 18.

17 Dyrektywa Parlamentu Europejskiego i Rady 2000/34/WE z dnia 22 czerwca 2000 r. zmieniająca dyrektywę Rady 93/104/WE dotyczącą niektórych aspektów organizacji czasu pracy, w celu objęcia sektorów i działalności wyłączeniem z tej dyrektywy, Dz. U. UE L, nr 195, poz. 41.

18 Dz. U. UE L, nr 299, poz. 9.

19 Z. Góral, op. cit., s. 181. 
- dobowego, trwającego co najmniej 11 godzin w każdym 24-godzinnym okresie oraz tygodniowego - w wymiarze 36 lub 24 godzin w okresie 7-dniowym. Dyrektywa zawiera także dość liczną listę wyjątków, które mogą powodować ograniczenie okresów wypoczynku bądź wydłużenie norm czasu pracy.

\section{Polskie unormowania w zakresie prawa do wypoczynku}

Zasada prawa do wypoczynku ma w Polsce rangę zasady konstytucyjnej. Artykuł 66 ust. 2 stanowi, że pracownik ma prawo do określonych w ustawie dni wolnych od pracy i corocznych płatnych urlopów. Umieszczenie tej zasady w Konstytucji RP świadczy o wadze, jaką prawodawca przykłada do tego zagadnienia. Jednocześnie warto zauważyć, że Konstytucja RP prawem do odpoczynku obejmuje pracowników, co każe postawić pytanie o zakres podmiotowy tego uprawnienia. Warto bowiem zauważyć tendencję do traktowania regulacji związanych z czasem pracy jako szeroko pojętych przepisów dotyczących bezpieczeństwa i higieny pracy. Zgodnie zaś z art. 66 ust. 1 Konstytucji RP, prawo do bezpiecznych i higienicznych warunków pracy nie jest zarezerwowane dla pracowników, ale przysługuje każdemu. Należy zatem stwierdzić, że prawodawca inaczej postrzega te uprawnienia, ograniczając prawo do wypoczynku jedynie do pracowników. Znajduje to odzwierciedlenie w przepisach rangi ustawowej, w Kodeksie pracy znaleźć można przepisy rozszerzające unormowania dotyczące BHP na osoby wykonujące pracę w oparciu o inne niż stosunek pracy podstawy zatrudnienia (art. 304 k.p.). Podobnej regulacji odnoszącej się do czasu pracy Kodeks pracy nie zawiera. Wśród innych ustaw, regulujących pozapracownicze stosunki zatrudnienia, czas wykonywania obowiązków unormowany jest jedynie w pragmatykach służbowych. Brak zatem takiej regulacji w stosunku do osób wykonujących pracę w ramach umów cywilnoprawnych. Powszechna w naszym kraju praktyka zawierania takich umów wskazuje na pilną potrzebę podjęcia prac nad taką regulacją, bowiem liczna rzesza pracujących pozostaje bez właściwej ochrony w tym zakresie.

Konstytucyjna zasada prawa do wypoczynku została niemal powtórzona w art. 14 Kodeksu pracy, choć warto zauważyć, że w Kodeksie wprost jest mowa o prawie do wypoczynku, którego Konstytucja RP literalnie nie nazywa. Kodeks pracy stanowi też główne źródło unormowań realizujących tę zasadę ${ }^{20}$.

Przepisy Kodeksu pracy o czasie pracy w dużej mierze wydają się zapewniać realizację papieskiego postulatu dotyczącego prawa do wypoczynku.

${ }^{20}$ Choć w stosunku do niektórych grup zawodowych realizację tej zasady określają przepisy szczególne (np. ustawa z dnia 16 kwietnia 2004 r. o czasie pracy kierowców, Dz. U. nr 92, poz. 879, ze zm.). 


\subsection{Normy czasu pracy}

Za przykład takich unormowań uznać należy ograniczenie czasu pracy poprzez wprowadzenie maksymalnej dobowej i przeciętnej tygodniowej normy czasu pracy w poszczególnych systemach. Mają one za zadanie chronić pracownika przed nadmierną eksploatacją pracą. Warto wspomnieć, że norma podstawowa ogranicza czas pracy do 8 godzin na dobę, co jest powszechnie przyjętym międzynarodowym standardem wypracowanym m.in. w wyniku działalności MOP. Charakter normy tygodniowej jako przeciętnej jest uzasadniony potrzebami elastycznego zarządzania pracą pracowników. Jednak odnotować należy, że także norma tygodniowa została zmieniona. Od 2001 r. w Kodeksie pracy pojawił się przepis o przeciętnie 5-dniowym tygodniu pracy ${ }^{21}$. Co za tym idzie, wprowadzono gwarancję, że pracodawca nie będzie pracowników angażował więcej niż przeciętnie 5 dni w tygodniu. Tę zasadę uzupełniono o stopniowe obniżenie przeciętnej tygodniowej normy z 42 do 40 godzin, bez czego zapewnienie 5-dniowego tygodnia pracy pozostałoby iluzoryczne.

\subsection{Okresy odpoczynku}

Niezwykle istotną regulację, która w dużej mierze realizuje postulat papieża Jana Pawła II w zakresie prawa do wypoczynku stanowią wprowadzone do Kodeksu pracy w 2003 r. okresy odpoczynku²2. Objęcie wszystkich pracowników okresami odpoczynku podyktowane było koniecznością dostosowania prawa polskiego do dyrektywy 93/104/WE z 13 grudnia 1993 r. dotyczącej niektórych aspektów organizacji czasu pracy. Kodeks zobowiązuje pracodawców do udzielania pracownikom dwóch rodzajów okresów odpoczynku - dobowego i tygodniowego.

Dyrektywa zobowiązuje państwa członkowskie do przyjęcia niezbędnych środków w celu zapewnienia, że każdy pracownik będzie uprawniony do minimalnego dobowego odpoczynku w wymiarze 11 nieprzerwanych godzin, w okresie 24-godzinnym. Polski ustawodawca realizując to zobowiązanie wprowadził do Kodeksu pracy art. 132; zgodnie z $\S 1$ pracownikowi przysługuje w każdej dobie prawo do co najmniej 11 godzin nieprzerwanego odpoczynku. Przepis ten odwołuje się do pojęcia doby, przez którą, zgodnie z definicją sformułowaną w art. $128 \S 3$ pkt 1 k.p., należy rozumieć 24 kolejne godziny, poczynając od godziny, w której pracownik rozpoczyna pracę, zgodnie z obowiązującym go rozkładem czasu pracy.

Wykonaniem art. 5 dyrektywy 2003/88/WE jest art. 133 Kodeksu pracy, który przewiduje uprawnienie pracownika do 35 godzin nieprzerwanego odpoczynku w każdym tygodniu. Okres 35 godzin odpoczynku obejmować ma 11 godzin

21 Ustawa z dnia 1 marca 2001 r. o zmianie ustawy - Kodeks pracy, Dz. U. nr 28, poz. 301.

22 Ustawa z dnia 14 listopada 2003 r. o zmianie ustawy - Kodeks pracy oraz o zmianie niektórych innych ustaw, Dz. U. nr 213, poz. 2081. 
odpoczynku dobowego, określonego w art. 132 k.p. Udzielając odpoczynku tygodniowego pracodawca pamiętać powinien o konieczności zachowania 11 godzin nieprzerwanego odpoczynku w dniu, w którym pracownik kończy pracę w danym tygodniu.

Okres odpoczynku tygodniowego, stosownie do art. $133 \S 3$ k.p., powinien przypadać w niedzielę. Niedziela nie pokrywa się z przyjętym powszechnie kalendarzowym rozumieniem tego terminu i obejmuje 24 kolejne godziny od godz. $6.00 \mathrm{w}$ niedzielę do godz. $6.00 \mathrm{w}$ poniedziałek, $\mathrm{z}$ tym że pracodawca może ustalić inne godziny. Warto zauważyć, że dyrektywa 2003/88/WE nie wprowadza obowiązku udzielania tygodniowego odpoczynku w niedzielę. Dyrektywa nr 93/104 w art. 5 zawierała normę, zgodnie z którą minimalny czas tygodniowej przerwy w pracy „powinien w zasadzie obejmować niedzielę”. Norma ta, podobnie jak kilka innych przepisów dyrektywy, została zaskarżona przez Wielką Brytanię do Trybunału Sprawiedliwości ${ }^{23}$. Trybunał w orzeczeniu z dnia 12 listopada $1996 \mathrm{r}^{24}$ uchylił przepis o udzielaniu odpoczynku tygodniowego w niedzielę. Orzeczenie to znalazło potwierdzenie w dyrektywie 2000/34/WE z 22 czerwca 2000 r. zmieniającej dyrektywę 93/104, której art. 1 ust. 3 uchylił część art. 5 nowelizowanej dyrektywy dotyczącą udzielania odpoczynku w niedzielę ${ }^{25}$. Wprowadzoną przez polskiego ustawodawcę zasadę udzielania tygodniowego okresu odpoczynku w niedzielę należy zatem uznać za przejaw polityki państwa, nie zaś za spełnianie postanowień prawa wspólnotowego. Można domniemywać, że przepis ten znalazł się w Kodeksie pracy jako spełnienie przez polskiego ustawodawcę postulatu wyrażanego przez Kościół katolicki, w tym przez Papieża Jana Pawła II.

Oba okresy odpoczynku stanowią niezwykle ważny instrument realizacji zasady prawa do wypoczynku. Należy podkreślić, że ich wprowadzenie miało daleko idące konsekwencje dla innych instytucji czasu pracy, m.in. godzin nadliczbowych. Wyrazić można żal, że tak istotna regulacja jest obciążona niedoróbkami legislacyjnymi, na co zwracano uwagę w literaturze ${ }^{26}$.

\subsection{Ograniczenia pracy w godzinach nadliczbowych}

Praca powinna być wykonywana w ramach norm czasu pracy, wynikających z przepisów regulujących poszczególne systemy czasu pracy. Jednak częstą sytuacją jest konieczność pracy dłuższej niż określona w tych przepisach. Praca ponad

23 Wielka Brytania zaskarżyła ponadto przepisy dotyczące m.in. ograniczenia czasu pracy łącznie z godzinami nadliczbowymi do 48 godzin tygodniowo, wprowadzenia przerwy w pracy w przypadku pracy trwającej dłużej niż 6 godzin dziennie, uprawnienia do czterech tygodni urlopu wypoczynkowego, alternatywnie domagała się uchylenia całej dyrektywy. Por. L. FLOREK, Europejskie prawo pracy, Warszawa 2005, s. 143.

${ }^{24}$ United Kingdom of Great Britain and Northern Ireland v Council of the European Union, 12.11.1996, C 84/94.

25 Por. M. Gersdorf, K. RączKA, J. SkoczYŃSKI, Kodeks pracy-komentarz, Warszawa 2004, s. 511.

26 Pro. np. A. SobczYk, op. cit., s. 227-236; K. Stefańskı, Okresy odpoczynku w kodeksie pracy, „Praca i Zabezpieczenie Społeczne” 2006, nr 1, s. 27-29. 
normy powinna być jednak ściśle reglamentowana, aby zapewnić pracownikom odpowiednią realizację prawa do wypoczynku. Polski ustawodawca ogranicza w różny sposób dopuszczalność zatrudniania pracowników w godzinach nadliczbowych.

Wskazać tu należy, w pierwszej kolejności, na ograniczenia przedmiotowe - związane z celem takiej pracy. Stosownie do art. $151 \S 1$ k.p., praca w godzinach nadliczbowych dopuszczalna jest jedynie w razie konieczności prowadzenia akcji ratowniczej lub w razie szczególnych potrzeb pracodawcy. Praca nadliczbowa wykonywania w celu realizacji potrzeb pracodawcy jest limitowana ilościowo - Kodeks pracy wprowadza limity roczne i dobowe (wynikające z dobowego okresu odpoczynku). Warto zauważyć, że poprzez określoną w art. 131 k.p. przeciętną maksymalną normę pracy w tygodniu, kodeks ogranicza zatrudnienie w godzinach nadliczbowych bez względu na cel takiej pracy. Polski ustawodawca zdecydował się na wprowadzenie również ograniczenia podmiotowego pracy w godzinach nadliczbowych. Pracy takiej nie mogą wykonywać m.in. kobiety w ciąży, młodociani oraz pracownicy zatrudnieni na stanowiskach, na których występują przekroczenia najwyższych dopuszczalnych stężeń i natężeń czynników szkodliwych dla zdrowia. Ograniczenia względne dotyczą niepełnosprawnych oraz osób wychowujących dzieci do lat czterech. Niewątpliwie do najważniejszych, z punktu widzenia pracodawcy, ograniczeń zatrudnienia w godzinach nadliczbowych należy środek ekonomiczny w postaci konieczności wypłaty dodatku za pracę w godzinach nadliczbowych. Konieczność wypłacenia dodatku w wysokości 50 lub 100\% wynagrodzenia jest często czynnikiem zniechęcającym pracodawców do zatrudniania pracowników w godzinach nadliczbowych, co nie pozostaje bez wpływu na realizację prawa do wypoczynku.

\subsection{Dni wolne}

Jeden z istotnych elementów zasady prawa do wypoczynku stanowią dni wolne od pracy. W polskim prawie dni te można podzielić na trzy kategorie - niedziele, święta oraz dni wynikające z pięciodniowego tygodnia pracy.

Niedziele są, stosownie do art. $151^{9}$ k.p., dniami wolnymi od pracy. Norma ta oznacza zakaz zatrudniania pracowników w tym dniu. Jednak dalsze przepisy Kodeksu pracy, a zwłaszcza art. $151^{10}$, wprowadzają liczne wyjątki od tej zasady. W dużej mierze osłabia to zasadę zakazu pracy w niedzielę. Wspomniane uregulowanie odpoczynku tygodniowego, który powinien przypadać w niedzielę pozwala mieć nadzieję, że pracodawcy nie będą nadużywać wyjątków określonych w art. $151^{10} \mathrm{i}$ wypoczynek niedzielny pozostanie prawem większości pracowników.

Święta, podobnie jak niedziele, są dniami wolnymi od pracy. Ustawa z 18 stycznia 1951 r. o dniach wolnych od pracy ${ }^{27}$ wprowadza katalog dni świątecznych. Katalog ten obejmuje trzynaście dni w roku, z czego dziewięć stanowią

27 Ustawa z dnia 18 stycznia 1951 r. o dniach wolnych od pracy, Dz. U. nr 4, poz. 28, ze zm. 
katolickie święta kościelne. Warto wspomnieć, że katalog świąt kościelnych, będących dniami wolnymi, został określony także w ustawie o stosunku Państwa do Kościoła katolickiego w Rzeczypospolitej Polskiej ${ }^{28}$. Jak zauważono w literaturze ${ }^{29}$, wprowadzając ostatnią zmianę, uwzględniającą święto Trzech Króli przypadające 6 stycznia ustawodawca pominął konieczność zawarcia porozumienia z władzami kościelnymi, co przewidują przepisy Konkordatu ${ }^{30}$.

Konsekwencją wprowadzenia zasady przeciętnie pięciodniowego tygodnia pracy stało się powstanie dni wolnych wynikających z takiego rozłożenia obowiązku pracy. Dni te mogą przypadać w różne dni tygodnia, jednak należy pamiętać o konieczności odpowiedniego zwolnienia pracownika z obowiązku świadczenia pracy.

\section{Zagrożenia dla realizacji prawa do wypoczynku}

Opisane przepisy prawa pracy w dużej mierze wypełniają papieskie postulaty o prawie pracowników do wypoczynku. Jednak nie sposób pominąć pewnych zagrożeń dla realizacji tego prawa, zwłaszcza, że niektóre z niech płyną z nowych regulacji.

Wśród zagrożeń wymienić należy z pewnością niektóre unormowania dotyczące pracy w godzinach nadliczbowych. Jak wspomniano wcześniej, ustawodawca ogranicza dopuszczalność pracy ponad normy wynikające z przepisów o systemach czasu pracy. Wprowadza jednak pewne wyjątki od tych ograniczeń. Przykład może stanowić przepis art. 151 § 4 k.p., który umożliwia zwiększenie rocznego limitu godzin nadliczbowych do ponad 150 godzin. Ustalenie wyższego limitu rocznego możliwe jest w układzie zbiorowym pracy, regulaminie pracy lub umowie, nie zawsze zatem pracownik będzie mógł wyrazić zgodę na taki zabieg. Warto także zauważyć, że obecna regulacja zatrudnienia ponadnormatywnego osób pracujących w niepełnym wymiarze czasu pracy może w istotny sposób ograniczać ich ramy wypoczynku. Pracownicy tacy, wybierając zatrudnienie niepełnoetatowe, czas wolny od pracy zamierzają przeznaczyć na inną działalność (edukacja, opieka nad członkami rodziny) lub na wypoczynek. Tymczasem w obecnym stanie prawnym pracodawca może zatrudniać takie osoby ponad normę wynikającą z ich wymiaru czasu pracy. Takie zatrudnienie najczęściej nie powoduje powstania uprawnienia do dodatku za pracę w godzinach nadliczbowych.

${ }^{28}$ Ustawa z dnia 17 maja 1989 r. o stosunku Państwa do Kościoła Katolickiego w Rzeczypospolitej Polskiej, Dz. U. nr 29, poz. 154, ze zm.

29 Por. M. Mielczarek, O święcie Trzech Króli jako dniu wolnym od pracy - głos w dyskusji, „Monitor Prawa Pracy” 2011, nr 1, s. 10; K. StefañskI, Problem świąt przypadających w dni wolne od pracy wynikające z pięciodniowego tygodnia pracy, „Praca i Zabezpieczenie Społeczne” 2010, nr 12, s. $16-18$.

${ }^{30}$ Konkordat między Stolicą Apostolską i Rzecząpospolitą Polską z dnia 28 lipca 1993 r., Dz. U. 1998, nr 51, poz. 318. 
Wprawdzie art. $151 \S 5$ k.p. przewiduje konieczność ustalenia w umowie o pracę dopuszczalnej liczby godzin, po przekroczeniu której pracownik będzie uprawniony do otrzymania dodatku. Jednak w wielu przypadkach takie ustalenia nie są czynione, a stanowisko Sądu Najwyższego zdaje się nie tylko akceptować takie zjawisko, lecz także przerzucać negatywne konsekwencje na pracownika. Stosownie bowiem do postanowienia Sądu Najwyższego, pracownikowi zatrudnionemu w niepełnym wymiarze czasu pracy nie przysługuje dodatek, o którym mowa w art. $151^{1} \S 1$ k.p. w razie nieustalenia na podstawie art. $151 \S 5$ k.p. dopuszczalnej liczby godzin pracy ponad określony w umowie wymiar czasu pracy ${ }^{31}$. Wśród zagrożeń dla wypoczynku pracownika można wymienić także regulację dotyczącą pracy w godzinach nadliczbowych osób zarządzających zakładem pracy w imieniu pracodawcy, a także kierowników wyodrębnionych komórek organizacyjnych. Osoby te wykonują pracę w godzinach nadliczbowych bez prawa do wynagrodzenia i dodatku, co powodować może chęć nadmiernej eksploatacji takich osób.

Zagrożenie dla realizacji prawa do wypoczynku może stanowić kodeksowe unormowanie dyżuru pracowniczego. Ustawodawca nie zalicza do czasu pracy okresu dyżuru, w którym pracownik nie świadczył pracy, ale przebywał w zakładzie pracy lub innym miejscu wyznaczonym przez pracodawcę $e^{32}$. W takim jednak przypadku pracownikowi przysługuje uprawnienie do czasu wolnego. Niestety, nie przysługuje ono pracownikom pełniącym dyżur w domu. Budzi to kontrowersje, nie można bowiem uznać, że $w$ trakcie takiego dyżuru pracownik dysponuje pełną swobodą i może wypoczywać w sposób przez siebie wybrany. Pozbawienie takiego pracownika jakichkolwiek uprawnień związanych z dyżurem pełnionym w takiej formie nie wydaje się rozwiązaniem właściwym. Warto wspomnieć, że w literaturze liczne są głosy o konieczności innego uregulowania tej kwestii ${ }^{33}$.

Niekiedy niebezpieczeństwo dla realizacji prawa do wypoczynku płynie z braku regulacji prawnej. Należy dostrzec, że brak unormowania podróży służbowej, a zwłaszcza zaliczenia czasu odbywania takiej podróży do czasu pracy nie wpływa korzystnie na możliwość wypoczynku pracownika. Warto dodać, iż zapatrywanie Sądu Najwyższego wskazuje, że okresu podróży służbowej nie można uznać za równoznaczny z pozostawaniem pracownika w dyspozycji pracodawcy, a nawet jeśli uznać, że w takiej dyspozycji pozostaje, to brak jest przesłanki, przewidzianej w art. 128 k.p., tj. warunku, aby miało to miejsce w zakładzie pracy lub innym miejscu, wyznaczonym do wykonywania pracy ${ }^{34}$. Jako argument tego rozumowania podnosi się to, że środek lokomocji nie stanowi miejsca wykonywania pracy. Ponadto podkreśla się, że w czasie podróży pracownik nie świadczy

\footnotetext{
31 Postanowienie Sądu Najwyższego z dnia 27 marca 2012 r., III PK 77/11, LEX nr 1214595.

32 Taka regulacja stanowi przedmiot krytyki w doktrynie - por. A. ZwoLINSKA, Dyżur, [w:] L. FLoREK, Czas pracy, Warszawa 2011, s. 110; K. STeFAńSKI, Czas pracy, Warszawa 2013, s. 31.

${ }_{33}$ Por. np. Ł. PISARCZYK, [w:] Kodeks pracy. Komentarz, red. L. Florek, Warszawa 2011, s. 828; W. OstaszewskI, M. Raczkowskı, Konstrukcja instytucji dyżuru pracowniczego i jej praktyczne wykorzystanie, „Praca i Zabezpieczenie Społeczne” 2012, nr 4, s. 27.

34 Uchwała Sądu Najwyższego z dnia 17 września 1985 r., III PZP 37/85 OSNCP, nr 6/198, poz. 94.
} 
pracy oraz nie pozostaje w dyspozycji pracodawcy w warunkach umożliwiających jego kontrolę. Podróż jest zatem dopiero drogą do wykonywania pracy ${ }^{35}$. Takie stanowisko nie zasługuje na aprobatę. Pracownik odbywa podróż w celu realizacji zadania nałożonego przez pracodawcę, a podróż stanowi niezbędny warunek tej realizacji. Można zatem uznać, że pracownik wykonuje swoje obowiązki i czas na to poświęcony winien być uznany za czas pracy ${ }^{36}$. Stanowisko to zdaje się potwierdzać analiza unormowań prawa wspólnotowego. Warto zauważyć, że dyrektywa 2003/88/WE wprowadza dychotomiczny podział na czas pracy i czas wypoczynku. Z pewnością czasu odbywania podróży służbowej nie można uznać za czas wypoczynku. Należy zatem uznać, że podróż służbowa powinna być traktowana jako czas pracy ${ }^{37}$.

Wśród zagrożeń dla realizacji prawa do wypoczynku można wymienić także niektóre nowe unormowania. $Z$ pewnością trzeba w tym kontekście rozpatrywać możliwość wydłużania okresów rozliczeniowych do 12 miesięcy, na co pozwala art. $129 \S 2$ w brzmieniu nadanym nowelizacją z 12 lipca 2013 r. ${ }^{38}$ Regulacja ta została wprowadzona w celu umożliwienia bardziej elastycznego zarządzania czasem pracy. Jednak dostrzec należy niebezpieczeństwa, jakie płyną z tej normy. Stosowanie długich okresów rozliczeniowych może prowadzić do nierównomiernego zapotrzebowania na pracę pracownika, a w konsekwencji - do konieczności długotrwałego wzmożonego wysiłku spowodowanego pracą w przedłużonym wymiarze. Z pewnością nie służy to odpowiedniemu wypoczynkowi. Ponadto wątpliwości budzą przesłanki wprowadzenia przedłużonych okresów rozliczeniowych. Według nowej regulacji, przedłużenie tych okresów jest dopuszczalne, gdy uzasadniają to przyczyny obiektywne lub techniczne lub dotyczące organizacji pracy. Są to warunki tożsame z regulacją art. 19 dyrektywy Parlamentu Europejskiego i Rady 2003/88/WE z dnia 4 listopada 2003 r. w sprawie niektórych aspektów organizacji czasu pracy ${ }^{39}$. Jak zauważono w doktrynie, takie sformułowanie dopuszczalne jest $w$ dyrektywie, jednak ustawodawca krajowy powinien być bardziej precyzyjny wprowadzając tak istotne regulacje ${ }^{40}$. Stwierdzić należy, że tego rodzaju klauzule generalne z jednej strony są pożądane, bowiem umożliwiają elastyczne stosowanie przepisów, jednak z drugiej strony można wyrazić obawę, czy wprowadzają wystarczające zabezpieczenie przed nadmierną eksploatacją pracowników. Trudno uznać, iż charakter wspomnianych klauzul pozwala na właściwą kontrolę wprowadzania przedłużonych okresów rozliczeniowych. Gwarancji ochrony pracowników trudno doszukać się także w regulacji, zgodnie z którą wprowadzenie przedłużonych okresów rozliczeniowych ma nastąpić przy

\footnotetext{
${ }^{35}$ Por. B. BuRY, Czas podróży służbowej, „Monitor Prawa Pracy” 2006, nr 8, s. 405.

36 Ibidem, s. 406.

37 Por. K. Stefański, Czas pracy, s. 38.

38 Ustawa z dnia 12 lipca 2013 r. o zmianie ustawy - Kodeks pracy oraz ustawy o związkach zawodowych, Dz. U. 2013, poz. 896.

${ }^{39}$ Dz. U. UE L, nr 299, poz. 9.

40 K. RAczKA, Elastyczny czas pracy, „Praca i Zabezpieczenie Społeczne” 2013, nr 7, s. 3.
} 
zachowaniu ogólnych zasad dotyczących bezpieczeństwa i zdrowia pracowników. Jest to również ogólnikowe uregulowanie, o którym trudno powiedzieć, że stanowi wystarczającą gwarancję dla pracowników.

\section{Uwagi końcowe}

Jak wynika z przeprowadzonych rozważań, polskie przepisy regulujące czas pracy w znacznym stopniu odpowiadają postulatom Jana Pawła II dotyczącym prawa pracowników do wypoczynku zamieszczonym m.in. w encyklice Laborem exercens. Można jednak dostrzec pewne zagrożenia. Wskazują one, iż nie można uznać, że Polska osiągnęła pełen sukces w tym obszarze. Należy także zwrócić uwagę, że przepisy dotyczące czasu pracy ewoluują i coraz wyraźniejsza staje się tendencja do uelastyczniania czasu pracy. Oznacza to, że pracodawcy mogą bardziej swobodnie zarządzać czasem pracy zatrudnionych pracowników. Zmieniając w tym kierunku przepisy, odchodzi się od ścisłego limitowania czasu pracy, określając jednak normy przeciętne i pozostawiając więcej swobody stronom stosunku pracy. Może to spowodować zagrożenie dla uprawnień pracowników, jednak należy zauważyć, iż oczekiwania pracowników m.in. co do czasu pracy i czasu odpoczynku podlegają także zmianom. Dość często można spotkać opinie, iż pracownicy wyrażają zgodę na pracę w większym rozmiarze, aby następnie, po określonym okresie, uzyskać więcej czasu wolnego. Temu mogą służyć nowoczesne rozwiązania wprowadzane w wielu krajach europejskich (np. konta czasu pracy). Wydaje się, że warto rozważać idącą w tym kierunku zmianę podejścia do przepisów prawa pracy w zakresie czasu pracy. Nie wolno jednak tracić z oczu potrzeby zapewnienia niezbędnych gwarancji dla pracowników, w tym prawa do wypoczynku. 